\title{
Real-time polymerase chain reaction-based identification of bacteria in milk samples from bovine clinical mastitis with no growth in conventional culturing
}

\author{
S. Taponen, ${ }^{* 1}$ L. Salmikivi,† H. Simojoki, ${ }^{*}$ M. T. Koskinen, $†$ and S. Pyörälä* \\ *University of Helsinki, Faculty of Veterinary Medicine, Department of Production Animal Medicine, Pohjoinen pikatie 800, FI-04920 Saarentaus, \\ Finland \\ †Finnzymes Oy, Keilaranta 16A, FI-02150 Espoo, Finland
}

\section{ABSTRACT}

In more than $30 \%$ of milk samples from clinical and subclinical bovine mastitis, bacteria fail to grow even after $48 \mathrm{~h}$ of conventional culture. The "no-growth" samples are problematic for mastitis laboratories, veterinarians, and dairy producers. This study provides the first investigation of the bacteriological etiology of such samples, using a real-time PCR-based commercial reagent kit. The assay targets the DNA of the 11 most common bacterial species or groups in mastitis and the staphylococcal blaZ gene (responsible for penicillin resistance) and can identify and quantify bacterial cells even if dead or growth-inhibited. A study was made of 79 mastitic milk samples with no-growth bacteria in conventional culture, originating from cows with clinical mastitis. Of the 79 samples, $34(43 \%)$ were positive for 1 (32 samples) or 2 (2 samples) of the target bacteria. The positive findings included 11 Staphylococcus spp. (staphylococci other than Staphylococcus aureus), 10 Streptococcus uberis, 2 Streptococcus dysgalactiae, 6 Corynebacterium bovis, 3 Staph. aureus, 1 Escherichia coli, 1 Enterococcus, and 1 Arcanobacterium pyogenes. The positive samples contained as many as $10^{3}$ to $10^{7}$ bacterial genome copies per milliliter of milk. This study demonstrates that in nearly half of the clinical mastitis cases in which conventional culture failed to detect bacteria, mastitis pathogens were still present, often in substantial quantities. The clearly elevated N-acetyl- $\beta$ D-glucosaminidase activity values of the milk samples, together with clinical signs of the infected cows and quarters, confirmed the diagnosis of clinical mastitis and indicated that real-time, PCR-based bacterial findings are able to reveal bacteriological etiology. We conclude that all common mastitis bacteria can occur in large quantities in clinical mastitis samples that exhibit no growth in conventional culture, and that the real-time

Received September 18, 2008.

Accepted February 13, 2009.

${ }^{1}$ Corresponding author: suvi.taponen@helsinki.fi
PCR assay is a useful tool for bacteriological diagnosis of such milk samples. Low bacterial concentration is commonly speculated to explain the no-growth milk samples. This hypothesis is not supported by the results of the current study.

Key words: mastitis, bacterial culture, no growth, polymerase chain reaction

\section{INTRODUCTION}

Mastitis remains the most common disease of dairy cattle, causing the biggest economic losses to the dairy industry (Halasa et al., 2007). Reliable identification of the causal bacteria is important for developing mastitis control strategies for dairy herds. Targeting antimicrobial treatment of animal infections such as mastitis against the causal agent is generally recommended (Constable et al., 2008). This is only possible with accurate identification of bacteria in the mastitic milk samples.

Bacteria do not grow in conventional culture in a substantial proportion of mastitic milk samples. According to the literature, no bacterial growth is detected in at least 20 to $30 \%$ of milk samples taken from udder quarters with clinical mastitis; in a study in the United Kingdom, the figure was 26.5\% (Bradley et al., 2007), in an earlier study in the United States, $27.2 \%$ (Hogan et al., 1989), and in Finnish studies 23.7\% (Koivula et al., 2007) and $27.1 \%$ (Nevala et al., 2004). An exceptionally high figure of $43.9 \%$ was recently reported in Canada (Olde Riekerink et al., 2008). In subclinical mastitis, samples with no bacterial growth are generally even more common; in various studies on subclinical mastitis, the percentage of culture-negative samples ranged from $28.7 \%$ (Koivula et al., 2007) to 38.6\% (Bradley et al., 2007). Makovec and Ruegg (2003) reported a figure of $49.7 \%$ without differentiating between subclinical and clinical mastitis. A negative result for a milk sample is not only frustrating for the farmer and the veterinarian submitting the sample, but also for the laboratory responsible for mastitis diagnostics. 
Possible reasons for no growth in milk samples can include low concentration of bacteria in the milk sample (Sears et al., 1990), pathogens not growing in standard culture media, or presence of substances in the milk decreasing the viability of bacteria in culture. The aim of this study was to use a real-time PCR-based assay (PathoProof Mastitis PCR Assay, Finnzymes Oy, Espoo, Finland) to study whether milk samples from clinical mastitis that showed no bacterial growth in conventional culturing contained mastitis pathogens. The assay was performed on milk samples without the need for bacterial culturing, and it identified a total of 11 mastitis-causing bacterial species or species groups. The analytical accuracy of the assay was validated in an earlier study, which demonstrated $100 \%$ analytical specificity and sensitivity, across a large collection of culture isolates originating from bovine clinical mastitis (Koskinen et al., 2009). Because the real-time PCR assay does not provide false-positive results (Koskinen et al., 2009) and because its sensitivity is not reliant on the viability of the bacteria to grow in culture, it provided an optimal tool to study the bacteriological etiology of the no-growth milk samples.

\section{MATERIALS AND METHODS}

Mastitis was classified as clinical if any clinical signs; for example, changes in milk appearance, were detected (IDF, 1999). Milk samples from commercial dairy herds were mainly collected by veterinarians during the daily practice of the Ambulatory Clinic of the Department of Production Animal Medicine, Faculty of Veterinary Medicine, University of Helsinki, Finland. The milk samples originated from a total of 67 cows from 46 commercial herds. Eight cows had 2 mastitic quarters sampled at the same time. The samples were collected during 2 years, from March 2003 to September 2005.

The anamnesis and clinical signs of the cows and SCC, as estimated using the California Mastitis Test, were recorded in the electronic patient records of the clinic. The clinical signs were classified as mild, moderate, or severe (IDF, 1999). The milk samples were cultured within a few hours after collection, using conventional methods; that is, $0.01 \mathrm{~mL}$ of milk was streaked onto blood agar and incubated at $37^{\circ} \mathrm{C}$. Agar plates were examined for growth after 18 to $24 \mathrm{~h}$ and after $48 \mathrm{~h}$ (Hogan et al., 1999). Only samples not producing colony-forming units on the blood agar were included in this study. Milk samples exhibiting no bacterial growth in culture were stored at $-20^{\circ} \mathrm{C}$ until further real-time PCR analysis in the laboratory of Finnzymes Oy (Espoo, Finland) and determination of milk N-acetyl- $\beta$-Dglucosaminidase (NAGase) activity in the laboratory of the Department of Production Animal Medicine
(Saari, Finland). In total, 79 no-growth samples were collected and used for this study.

\section{Real-Time PCR Assay}

Identification of bacterial DNA was done using a real-time PCR based commercial reagent kit (PathoProof Mastitis PCR Assay, Finnzymes Oy). The assay included all necessary reagents for DNA extraction and real-time PCR. The DNA extraction method used 70 $\mu \mathrm{L}$ of milk as the starting material and involved an enzymatic lysis step, disrupting the cell walls of grampositive and gram-negative bacteria, as well as purification and elution steps.

The assay targeted the following 11 prevalent mastitis causing bacterial species or groups: 1) Staphylococcus aureus, 2) Staphylococcus spp., including Staph. aureus and the most relevant CNS (Staph. chromogenes, Staph. epidermidis, Staph. hemolyticus, Staph. hyicus, Staph. lugdunensis, Staph. saprophyticus, Staph. simulans, Staph. warneri, and Staph. xylosus), 3) Streptococcus agalactiae, 4) Strep. dysgalactiae, 5) Strep. uberis, 6) E. coli, 7) Enterococcus spp., including E. faecalis and E. faecium, 8) Klebsiella spp., including $K$. oxytoca and $K$. pneumoniae, 9) Corynebacterium bovis, 10) Arcanobacterium pyogenes and Peptoniphilus indolicus, and 11) Serratia marcescens. In addition, the assay targeted the staphylococcal $\beta$-lactamase penicillin resistance gene (blaZ). The assay identified Staphylococcus spp., Enterococcus spp., Klebsiella spp., and A. pyogenes/P. indolicus to their species group levels; for example, $E$. faecalis and E. faecium were identified in the same realtime PCR reaction and instrument channel.

The analytical accuracy of the assay was previously studied using a collection of 643 culture isolates, representing 83 different bacterial species or species groups, and originating from 6 countries in Europe and North America. The specificity and sensitivity of the assay were shown to be $100 \%$ across all of the strains isolated from bovine mastitis (Koskinen et al., 2009). This information was highly relevant for the scope of the current study, indicating that the positive results indeed were true positives, rather than false-positive results (i.e., samples yielding positive results in real-time PCR indeed contained bacterial DNA from the respective species).

The assay protocol involved 4 separate multiplex real-time PCR reactions, each of which amplified 3 bacterial targets, and an internal amplification control (IAC; Figure 1) composed of a 93-bp fragment of lambda DNA. The reactions were set up by combining $5 \mu \mathrm{L}$ of the extracted DNA with $10 \mu \mathrm{L}$ of Master Mix (including $\mathrm{MgCl}_{2}$, deoxynucleoside triphosphates, and hot-start DNA polymerase in an optimized buffer) with 


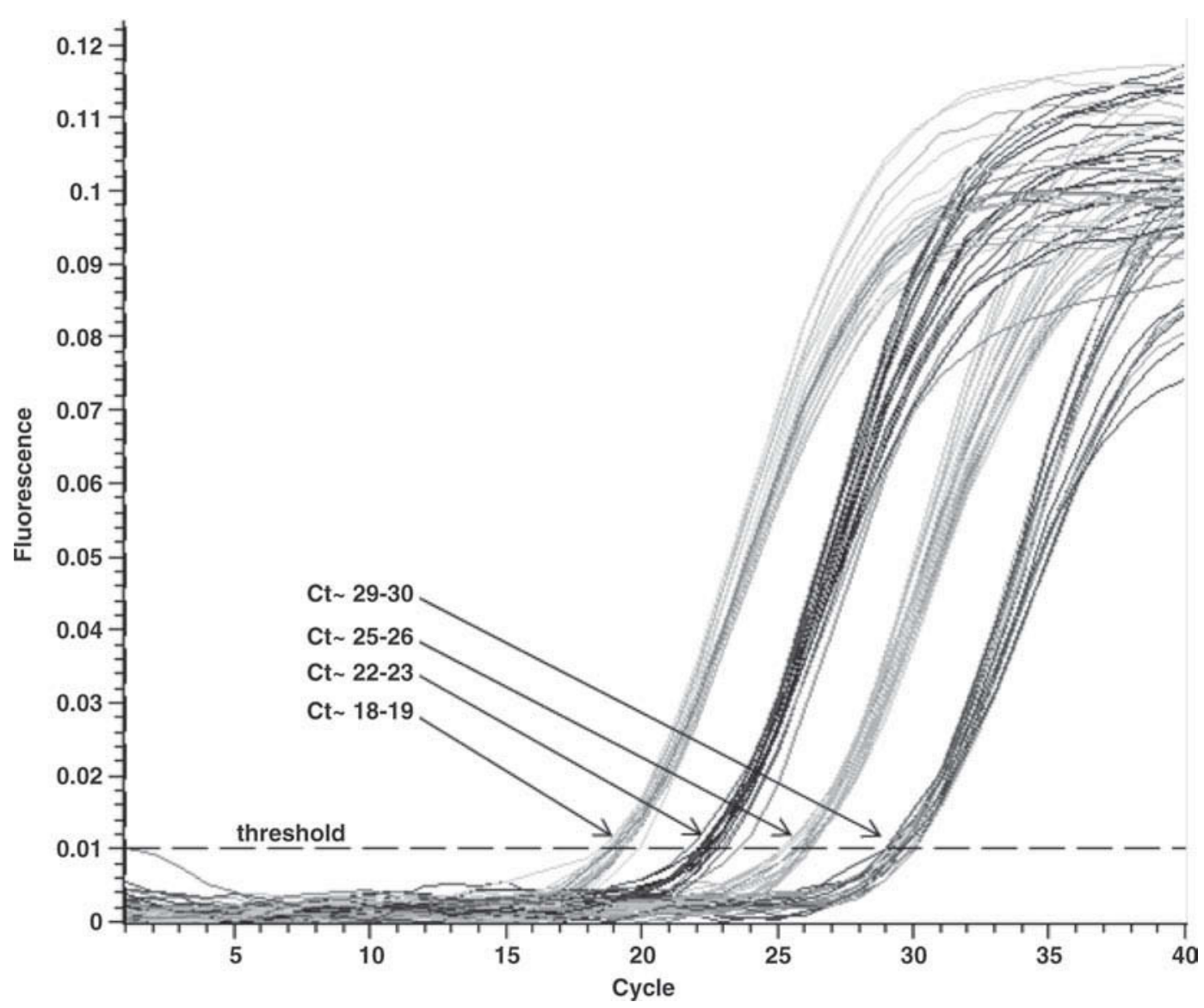

Figure 1. The internal amplification control (IAC) real-time PCR curves obtained from the 4 reactions of the PCR assay for 16 of the milk samples included in this study. $\mathrm{Ct}=$ cycle threshold.

$5 \mu \mathrm{L}$ of reaction-specific Primer Mix 1,2,3, or 4. The primer mixes 1 to 4 included the species-specific primers and probes employed in the assay, IAC-specific primers and probes, as well as IAC DNA (in $10^{3}, 10^{4}, 10^{5}$, and $10^{6}$ copies for primer mix $1,2,3$, and 4 , respectively).

A Bio-Rad Chromo 4 (Bio-Rad Laboratories, Hercules, CA) real-time PCR instrument was used. The thermal cycling protocol involved a 10-min predenaturation phase at $95^{\circ} \mathrm{C}$, and 40 cycles of 5 -s denaturation at $95^{\circ} \mathrm{C}$ and $60-\mathrm{s}$ annealing at $60^{\circ} \mathrm{C}$. The plate reads were always completed following the annealing step of the 2-step thermal cycling protocol.

Fluorescence threshold settings were adjusted for the real-time PCR instrument according to the assay user manual and amplification standard, which included 20,000 copies $/ \mu \mathrm{L}$ of the target sequence for each of the bacterial targets. Before scoring a reaction as negative, it was always confirmed that the IAC produced an amplification curve characteristic of an acceptable reaction (Figure 1) and that a cycle threshold $(\mathbf{C t})$ value was obtained that fit the acceptable $\mathrm{Ct}$ range of the reagent kit (reaction 1 : $\mathrm{IAC} \mathrm{Ct}=28.5-31.5$; reaction 2 :
$\mathrm{IAC} \mathrm{Ct}=24.5-27.5$; reaction $3: \mathrm{IAC} \mathrm{Ct}=21.5-24.5$; reaction 4 : IAC $\mathrm{Ct}=18.5-21.5)$. A negative control (deionized ultrapure water, $\mathbf{d H}_{2} \mathbf{O}$ ) was included in every real-time PCR and for each multiplex PCR reaction to confirm that cross-contamination had not occurred in the laboratory.

A 10-fold dilution series of the assay amplification standard $\left(10^{0}\right.$ to $\left.10^{-3}\right)$ was prepared in $\mathrm{dH}_{2} \mathrm{O}$ and 5 $\mu \mathrm{L}$ of the dilutions were used in 6 replicates for each multiplex PCR reaction. The results obtained for the dilutions, corresponding to $10^{5}, 10^{4}, 10^{3}$, and $10^{2}$ copies of the target sequences per PCR reaction, were used to prepare standard curves for each bacterial target (Figure 2). The DNA concentrations, measured by spectrophotometer, were converted to copy numbers as follows:

$$
n=\frac{N_{A} \cdot m}{M_{w} \cdot L},
$$

where $n=$ number of target sequence copies in microliter $($ copies $/ \mu \mathrm{L}) ; N_{A}=$ Avogadro's constant $\left(\mathrm{mol}^{-1}\right) ; m$ 


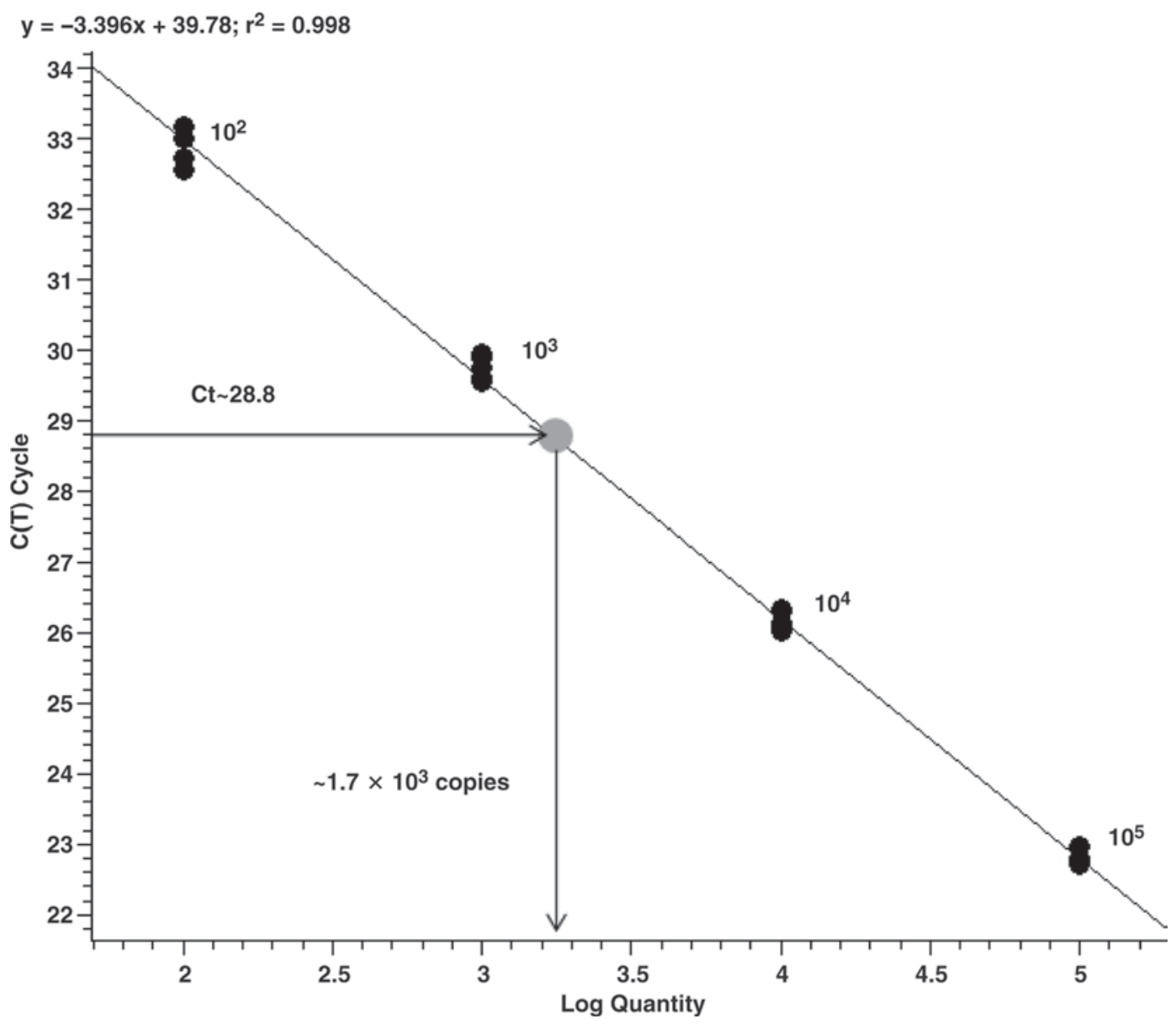

Figure 2. Staphylococcus spp. standard curve generated using a 10-fold dilution series of the amplification standard included in the PCR assay. The dilutions correspond to $10^{5}$ to $10^{2}$ copies of the Staphylococcus spp. target sequence per PCR reaction, and 6 replicates were run for each dilution. The results obtained for sample number 45 exemplify how the absolute quantification method applied in this study is used to determine the bacterial quantities: the cycle threshold value of the sample $(\mathrm{Ct}=28.8)$ is plotted on the standard curve, and the corresponding bacterial quantity in the PCR reaction $\left(\sim 1.7 \times 10^{3}\right.$ copies $)$ is obtained from the x-axis.

$=$ mass of the amplicon in microliter $(\mathrm{ng} / \mu \mathrm{L}) ; M_{w}=$ mean molecular weight of $1 \mathrm{bp}(\mathrm{g} / \mathrm{mol}$ per base pair); and $L=$ amplicon length in bp. The Ct values obtained were plotted on the respective standard curves to convert the $\mathrm{Ct}$ values to copies of target sequence per $\mathrm{PCR}$ reaction (Figure 2).

\section{Determination of Milk NAGase Activity}

Milk NAGase activity of the samples was measured to determine the inflammation reaction of the quarters. A fluorometric method, modified from the method of Mattila and Sandholm (1985), was used. A calibrated milk sample was replaced with a control milk sample with known 4-methyl-umbellipheron (4-MU) concentration and NAGase activity was expressed as picomoles of $4-\mathrm{MU} / \mathrm{min}$ per microliter of milk at $25^{\circ} \mathrm{C}$ instead of arbitrary units. The lower detection limit for
NAGase activity was $0.1 \mathrm{pmol}$ of $4-\mathrm{MU} / \mathrm{min}$ per $\mu \mathrm{L}$ of milk, and the upper detection limit was $24.49 \mathrm{pmol}$ of $4-\mathrm{MU} / \mathrm{min}$ per $\mu \mathrm{L}$ of milk. For statistical analyses, the samples that exceeded the upper detection limit were given a NAGase value of $25 \mathrm{pmol}$ of $4-\mathrm{MU} / \mathrm{min}$ per $\mu \mathrm{L}$ of milk. The interassay and intraassay coefficients of variation for the NAGase activity analyses were 4.9 and $3.9 \%$, respectively. As an internal laboratory standard, a mean NAGase value for healthy quarters was calculated using 46 milk samples from 8 cows with clinically healthy udders, low milk SCC $(<100000$ cells/ $\mathrm{mL}$ ), and with no bacterial growth in the quarter milk samples. The mean of the milk NAGase values of these healthy quarters was $0.36 \mathrm{pmol}$ of $4-\mathrm{MU} / \mathrm{min}$ per $\mu \mathrm{L}$ of milk (SE $0.02 \mathrm{pmol}$ of $4-\mathrm{MU} / \mathrm{min}$ per $\mu \mathrm{L}$ of milk). The minimum and maximum NAGase values of healthy quarters were 0.18 and $0.66 \mathrm{pmol}$ of $4-\mathrm{MU} / \mathrm{min}$ per $\mu \mathrm{L}$ of milk, respectively. 


\section{Statistical Analyses}

The possible differences in mean NAGase activity in milk samples, with and without detection of bacterial DNA, and with DNA of different bacteria, were calculated using ANOVA. The milk NAGase activity was the dependent factor and existence of bacterial DNA (yes/no) the independent factor. Chi-square test was used to test the possible difference in proportion of mild versus moderate to severe clinical signs between cows with a milk sample positive versus negative for bacterial DNA.

\section{RESULTS}

\section{Real-Time PCR Assay}

Of the 79 milk samples $34(43 \%)$ were positive for 1 (32 samples) or 2 (2 samples) of the real-time PCR assay target bacteria (Table 1). Streptococcus uberis was detected in 10 samples, Staphylococcus spp. were detected in 9 samples, and Staphylococcus spp. together with Strep. dysgalactiae in 1 sample, and together with $C$. bovis in 1 sample. Corynebacterium bovis was detected in 5 samples and Strep. dysgalactiae in 2 samples. Staphylococcus aureus was detected in 3 samples. Arcanobacterium pyogenes/P. indolicus, E. coli, and Enterococcus faecalis/faecium were detected in 1 sample each. The staphylococcal $\beta$-lactamase gene was detected in 3 samples with non-aureus staphylococci (Table 1).

The Ct values obtained for the bacterial targets ranged from 22.2 to 36.7 (average 32.3, SD 3.70). The standard curves prepared using the assay amplification standard (Figure 2) were reliable, the $\mathrm{R}^{2}$ (the coefficient of determination) values ranging from 0.988 to 0.999 (average 0.995, SD 0.004; Figure 2). By applying absolute quantification based on the standard curves, the positive samples were calculated to contain $<10$ to $>7,000$ (average 494, SD 1,489) bacterial genome copies per PCR reaction (Table 1). As the DNA extraction procedure of the assay used $70 \mu \mathrm{L}$ of milk, these numbers translate into $\sim 2,230$ to more than $10^{7}$ bacterial genome copies per $1 \mathrm{~mL}$ of milk (Table 1 ).

The IAC always provided an amplification curve characteristic of an acceptable PCR reaction (Figure 1). Furthermore, the IAC Ct values were within the ranges provided in the assay user manual. The amplification curves for all of the IAC also formed discrete clusters for each of the reactions, when the curves obtained across samples were overlaid (Figure 1). These observations indicated that PCR inhibition, or human errors in connection with reaction set-up, did not cause falsenegative results. The negative control samples never delivered positive amplification signals, indicating that laboratory contamination did not cause false-positive results.

\section{Milk NAGase Activity}

Median NAGase activity value of all samples was 18.7 pmol of $4-\mathrm{MU} / \mathrm{min}$ per $\mu \mathrm{L}$ of milk, the minimum 0.75 pmol of $4-\mathrm{MU} / \mathrm{min}$ per $\mu \mathrm{L}$ of milk, and the maximum upper detection limit $24.49 \mathrm{pmol}$ of $4-\mathrm{MU} / \mathrm{min}$ per $\mu \mathrm{L}$ of milk; that is, values of all samples exceeded the highest value of the control samples taken from healthy quarters. In 27 (34\%) samples NAGase activity was under $10 \mathrm{pmol}$ of $4-\mathrm{MU} / \mathrm{min}$ per $\mu \mathrm{L}$ of milk, in 30 samples (38\%) under $24.3 \mathrm{pmol}$ of $4-\mathrm{MU} / \mathrm{min}$ per $\mu \mathrm{L}$ of milk, and in 22 samples (28\%), NAGase activity exceeded the upper detection limit. The mean NAGase activity of milk samples in which bacterial DNA was detected (17.6 pmol of 4-MU/min per $\mu \mathrm{L}$ of milk) did not differ significantly from the mean NAGase activity of milk samples in which bacterial DNA was not detected (14.4 pmol of $4-\mathrm{MU} / \mathrm{min}$ per $\mu \mathrm{L}$ of milk; $P=0.102$ ).

\section{Clinical Signs}

Clinical signs of mastitis were mild or moderate in most cases. Moderate or severe signs were more often seen in cows in which bacterial DNA was detected in the milk sample ( $42 \%$ moderate to severe signs) compared with cows from which bacterial DNA was not detected (11\% moderate to severe signs; $P<0.05$ ).

\section{DISCUSSION}

Milk samples from cows with mastitis often fail to show bacterial growth in conventional culture. This is a major problem in subclinical mastitis but also common in clinical mastitis, and is a concern for all mastitistesting laboratories, veterinarians, and dairy producers. The present study is the first to investigate the bacteriological etiology of such no-growth samples. The absence of such studies is likely because PCR-based methods able to identify and quantify the principal mastitis pathogens in cow milk have been unavailable until recently. The real-time PCR assay employed here (Koskinen et al., 2009) provided a convenient means to study the no-growth samples. Of the 79 milk samples studied, almost half showed a positive bacteriological result in the PCR assay. Most common mastitis pathogens were detected and were often found in high quantities.

Low concentration of bacteria in milk has been proposed as one reason for no growth in bacterial culturing. Bacterial culturing generally uses $0.01 \mathrm{~mL}$ of milk 
Table 1. Recorded bacterial species, cycle threshold $(\mathrm{Ct})$ values, number of genome copies per PCR reaction, and number of genome copies per milliliter of milk in milk samples analyzed with a real-time PCR-based commercial reagent kit ${ }^{1}$

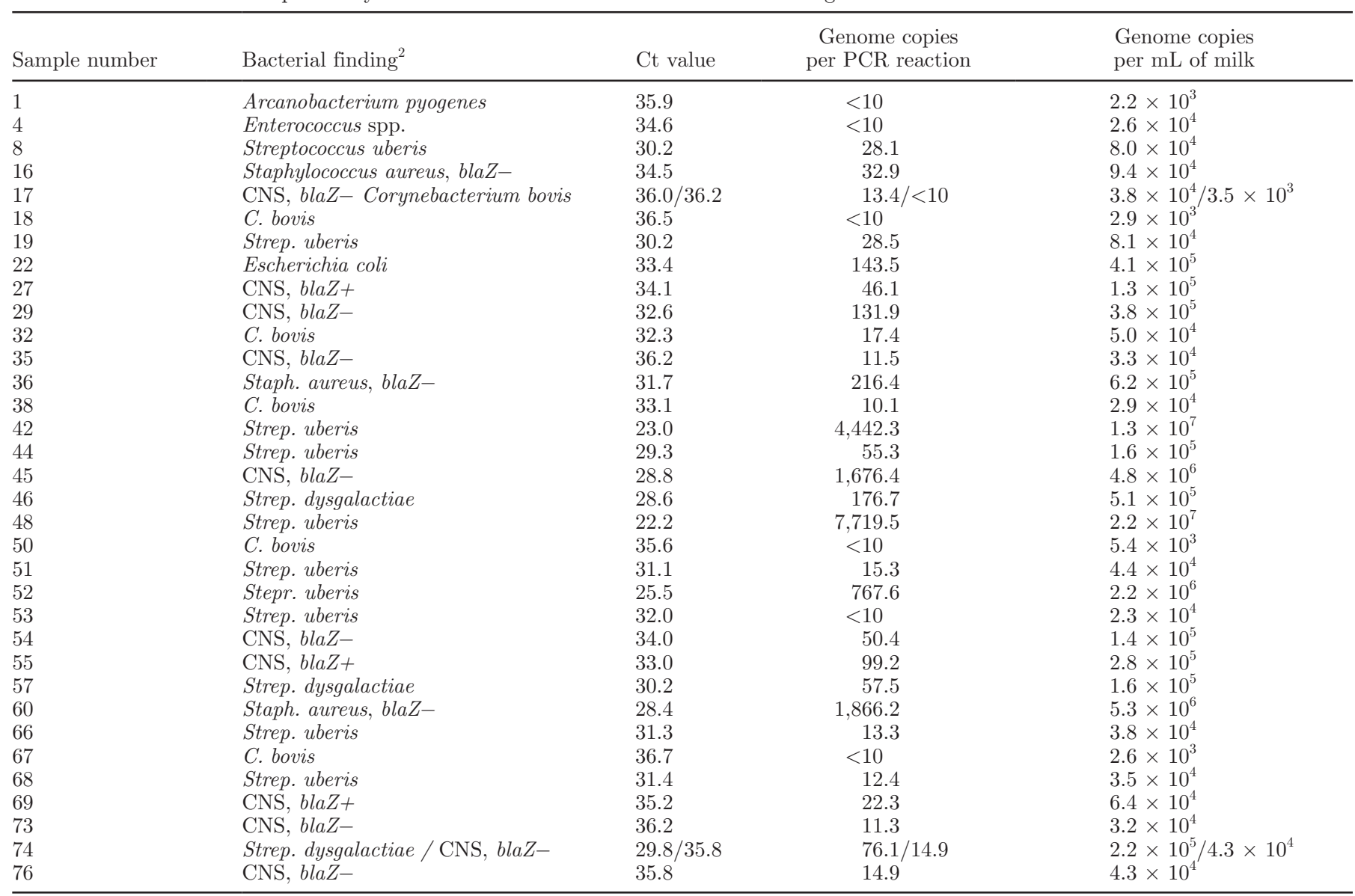

${ }^{1}$ The milk samples, originating from quarters of dairy cows with clinical mastitis, were negative for conventional bacterial culturing. Only samples positive for bacterial DNA (34 out of 79) are included in the table.

${ }^{2} b l a \mathrm{Z}=$ staphylococcal $\beta$-lactamase penicillin resistance gene.

(Hogan et al., 1999). The detection limit for bacterial growth in culture using $0.01 \mathrm{~mL}$ of milk is $100 \mathrm{cfu} / \mathrm{mL}$. Preculture incubation, preculture freezing, and use of larger plate inoculation volumes were shown to reduce the proportion of samples with no growth (Schukken et al., 1989; Dinsmore et al., 1992), but the effect of preculture freezing may be different for different bacteria (Schukken et al., 1989). Based on the present results with the quantitative real-time PCR assay, it seems unlikely that a low concentration of bacteria in the milk samples would be the sole explanation for the negative culture results. For example, the lowest $\mathrm{Ct}$ value obtained was 22.2 , which was calculated to correspond to more than $10^{7}$ bacterial genomes per $1 \mathrm{~mL}$ of milk. One bacterial cell can correspond to 1 cfu but it is unlikely that all bacterial cells in a sample would grow on the culture media. In milk samples, bacteria can be present in aggregates or, like staphylococci and streptococci, in chains, with each aggregate or chain forming one colony on agar. However, even with these potential sources of bias, it seems unlikely that the high bacterial copy numbers identified by real-time PCR would be insufficient to provide positive results in culture. Other reasons must thus exist to explain the negative result for these PCR-positive samples.

The Ct range for the no-growth PCR positive samples was 22.2 to 36.7 , with an average $\mathrm{Ct}$ of 32.3 . To put these values into perspective, it is useful to note that in another study of clinical mastitis milk samples providing positive culture results $(\mathrm{n}=391)$, the real-time PCR assay delivered Ct values of 12.9 to 37.0 (average $\mathrm{Ct}=28.8, \mathrm{SD}=4.8)$ for the respective bacterial species (M. T. Koskinen; unpublished results). Although a detailed analysis of culture positive results is beyond the scope of this study, it is clear that many of the nogrowth samples included in this study contained much higher bacterial concentrations than is the case with some culture positive samples from clinical mastitis. 
Poor viability or death of bacteria in the sample due to antibacterial factors of the milk could be one reason for no growth. Milk contains many antibacterial substances such as lactoferrin, lysozyme, lactoperoxidase, components of complement, and immunoglobulins (Rainard and Riollet, 2006). Their concentrations remain at a low level in healthy quarters, but substantially increase during mastitis. It can be hypothesized that these substances, operating in synergy with milk leukocytes, could contribute to death of bacteria in mastitic milk. Presence of external inhibitory substances in the milk is also possible; information about possible antibiotic treatment of the cow before sampling may not be available, or residues from disinfectants used to clean the teat may inhibit the bacterial growth.

Another reason for lack of bacterial growth in mastitic milk could be that a culture-negative milk sample contains bacteria that do not grow on conventional media, such as anaerobes or Mycoplasma. However, the global incidence of Mycoplasma mastitis is not so high that it could explain the high number of culturenegative results reported from different countries (Fox, 2006). Mycoplasma mastitis is mainly a problem in certain regions of North America (González and Wilson, 2003) and has not been reported in the Nordic countries. Mastitis due to strict anaerobes alone is very rare (Radostits et al., 2007); the most common form of mastitis involving anaerobes is the so-called summer mastitis, for which A. pyogenes and P. indolicus are the main pathogens, alone or together with other bacteria (Pyörälä et al., 1992). The present study showed that no single mastitis-causing species was dominant, but many bacteria were present in the samples. Several authors have suggested that quarters with no bacterial growth would be infected by $E$. coli, which were then rapidly eliminated (Olde Riekerink et al., 2008). Our results did not support this theory as only one milk sample contained DNA of E. coli. The same was reported by Waage et al. (1994) who, using the Limulus amoebocyte lysate (LAL) test, found LPS of gram-negative bacteria in only 2 of the 57 milk samples with no growth. On the other hand, it is possible that rapidly eliminated $E$. coli were not detected by the PCR assay but the inflammatory reaction was still present in quarters with no bacterial DNA.

It should be noted that in $58 \%$ of the milk samples, bacterial DNA was not detected by the real-time PCR assay, which could suggest that reasons other than a bacterial infection cause the clinical signs and inflammatory reaction in the udder quarter of these cows. Environmental factors, including draft, trauma, or a virus infection can, in theory, cause an inflammatory response. However, it is more likely that cases without bacterial DNA may be of infectious origin, but bacte- ria may have been eliminated from the quarter. Experimental models have shown that in bovine mastitis, clinical signs (in particular the inflammatory reaction such as a high SCC) in the milk remain in the quarter for days after clearing the infection (Pyörälä and Mattila, 1987; Suojala et al., 2008). Cows without bacterial DNA in their milk showed significantly milder clinical signs compared with those with a positive finding, which could also indicate that possible infection had been eliminated earlier in the first group.

\section{CONCLUSIONS}

Culture-negative milk samples represent a large proportion of samples in conventional bacteriology and are frustrating for the laboratory, the veterinarian, and the dairy producer. Real-time PCR could provide a bacteriological diagnosis for almost half of the cases where conventional culture results are negative. Most common mastitis pathogens were detected in the nogrowth milk samples and they were often present in large numbers. The PCR-based method is a useful tool to resolve bacterial etiology of milk samples with no growth in conventional culturing.

\section{REFERENCES}

Bradley, A. J., K. A. Leach, J. E. Breen, L. E. Green, and M. J. Green. 2007. Survey of the incidence and aetiology of mastitis on dairy farms in England and Wales. Vet. Rec. 160:253-258.

Constable, P., S. Pyörälä, and G. Smith. 2008. Guidelines for antimicrobial use in cattle. Pages 143-160 in Guide to Antimicrobial Use in Animals. L. Guardabassi, L. B. Jensen, and H. Kruse, ed. Blackwell Publishing Ltd., Oxford, UK.

Dinsmore, R. P., P. B. English, R. N. Gonzalez, and P. M. Sears. 1992. Use of augmented cultural techniques in the diagnosis of the bacterial cause of clinical bovine mastitis. J. Dairy Sci. 75:27062712 .

Fox, L. 2006. Mycoplasma mastitis: It just won't go away. Page 197 in Proc. National Mastitis Council, 45th Annual Meeting Proceedings, Tampa, Florida. Natl. Mastitis Counc., Madison, WI.

González, R. N., and D. J. Wilson. 2003. Mycoplasmal mastitis in dairy herds. Vet. Clin. North Am. Food Anim. Pract. 19:199-221.

Halasa, T., K. Huijps, O. Østerås, and H. Hogeveen. 2007. Economic effects of bovine mastitis and mastitis management: A review. Vet. Q. 29:18-31.

Hogan, J. S., R. N. González, R. J. Harmon, S. C. Nickerson, S. P. Oliver, J. W. Pankey, and K. L. Smith. 1999. Laboratory Handbook on Bovine Mastitis. Rev. ed. National Mastitis Council, Madison, WI.

Hogan, J. S., K. L. Smith, K. H. Hoblet, P. S. Schoenberger, D. A. Todhunter, W. D. Hueston, D. E. Pritchard, G. L. Bowman, L. E. Heider, and B. L. Brockett. 1989. Field survey of clinical mastitis in low somatic cell count herds. J. Dairy Sci. 72:1547-1556.

IDF. 1999. Suggested interpretation of mastitis terminology. International Dairy. Fed. Bull. 3-26.

Koivula, M., A. Pitkälä, S. Pyörälä, and E. Mäntysaari. 2007. Distribution of bacteria and seasonal and regional effects in a new database for mastitis pathogens in Finland. Acta Agric. Scand. A 57:89-96.

Koskinen, M. T., J. Holopainen, S. Pyörälä, P. Bredbacka, A. Pitkälä, H. W. Barkema, R. Bexiga, J. Roberson, L. Sølverod, R. Piccinini, 
D. Kelton, H. Lehmusto, S. Niskala, and L. Salmikivi. 2009. Analytical specificity and sensitivity of a real-time PCR assay for identification of bovine mastitis pathogens. J. Dairy Sci. 92:952959.

Makovec, J. A., and P. L. Ruegg. 2003. Results of milk samples submitted for microbiological examination in Wisconsin from 1994 to 2001. J. Dairy Sci. 86:3466-3472.

Mattila, T., and M. Sandholm. 1985. Antitrypsin and N-acetyl- $\beta$-Dglucosaminidase as markers of mastitis in a herd of Ayrshire cows. Am. J. Vet. Res. 46:2453-2456.

Nevala, M., S. Taponen, and S. Pyörälä. 2004. Bacterial etiology of bovine clinical mastitis - Data from Saari Ambulatory Clinic in 2002-2003. Suomen Eläinlääkärilehti (Finnish Vet. J.) 110:363369

Olde Riekerink, R. G., H. W. Barkema, D. F. Kelton, and D. T. Scholl. 2008. Incidence rate of clinical mastitis on Canadian dairy farms. J. Dairy Sci. 91:1366-1377.

Pyörälä, S., H. Jousimies-Somer, and M. Mero. 1992. Clinical bacteriological and therapeutic aspects of bovine mastitis caused by aerobic and anaerobic pathogens. Br. Vet. J. 148:54-62.

Pyörälä, S., and T. Mattila. 1987. Inflammatory changes during experimental bovine mastitis induced by Staphylococcus aureus, Streptococcus dysgalactiae and Streptococcus uberis. J. Vet. Med. A. $34: 574-581$.
Radostits, O. M., C. C. Gay, K. W. Hinchcliff, and P. D. Constable. 2007. Diseases of the mammary gland. Page 673 in Veterinary Medicine: A textbook of the diseases of cattle, sheep, pigs, goats and horses. 10th ed. Elsevier Ltd., Philadelphia, PA.

Rainard, P., and C. Riollet. 2006. Innate immunity of the bovine mammary gland. Vet. Res. 37:369-400.

Schukken, Y. H., J. A. H. Smit, F. J. Grommers, D. Vandegeer, and A. Brand. 1989. Effect of freezing on bacteriologic culturing of mastitis milk samples. J. Dairy Sci. 72:1900-1906.

Sears, P. M., B. S. Smith, P. B. English, P. S. Herer, and R. N. González. 1990. Shedding pattern of Staphylococcus aureus from bovine intramammary infections. J. Dairy Sci. 73:2785-2789.

Suojala, L., T. Orro, H. Järvinen, J. Saatsi, and S. Pyörälä. 2008. Acute phase response in two consequent experimentally induced E. coli intramammary infection in dairy cows. Acta Vet. Scand. 50:18.

Waage, S., P. Jonsson, and A. Franklin. 1994. Evaluation of a cow-side test for detection of gram-negative bacteria in milk from cows with mastitis. Acta Vet. Scand. 35:207-212 